\title{
Three New Labdanes Isolated from Eragrostis viscosa
}

\author{
N’Soki N. Sebastião, ${ }^{a}$ Nelson Fernandes, ${ }^{b}$ Liliana Vieira, ${ }^{b}$ António J. G. Mendonça, ${ }^{c}$ \\ Jorge F. Gaspar, ${ }^{d}$ Celia Martins, ${ }^{d}{ }^{J}$ José Rueff, ${ }^{d}$ Carlos Diakanamwa ${ }^{e}$ and \\ Dina I. M. D. de Mendonça*,b
}

${ }^{a}$ Chemistry Department, Agostinho Neto University, Av. 4 de Fevereiro $n^{\circ}$ 7, Luanda, Angola

${ }^{b}$ Textile and Paper Materials Center and Chemistry Department, University of Beira Interior, 6200-001 Covilhã, Portugal

${ }^{c}$ CICS-UBI - Health Sciences Research Centre, University of Beira Interior, Av. Infante D. Henrique, 6200-506 Covilhã, Portugal

${ }^{d}$ Genetics Department, Faculty of Medical Sciences, New University of Lisbon, 1349-008 Lisboa, Portugal

${ }^{e}$ Biology Department, Agostinho Neto University, Av. 4 de Fevereiro $n^{\circ}$ 7, Luanda, Angola

Três novos labdanos com anel $8 \alpha, 15$-epoxi [ $8 \alpha, 15$-epoxilabdan-16 $\beta$-oato de metila,

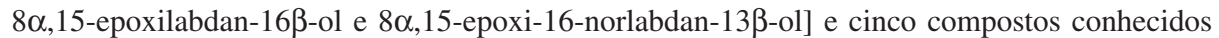

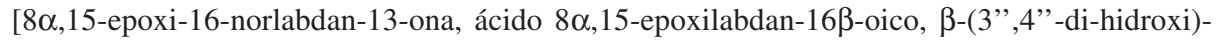
(E)-cinamoiloxilup-20(29)-eno, 3-(2',3',4',6'-tetra- $O$-acetil- $\beta$-D-glucopiranosiloxi)- $\beta$-sitosterol e 16-acetoxi-8 $\alpha, 15$-epoxilabdano] foram isolados dos extratos de tolueno e diclorometano de partes aéreas da Eragrostis viscosa. A estrutura dos compostos foi atribuída a partir dos seus dados

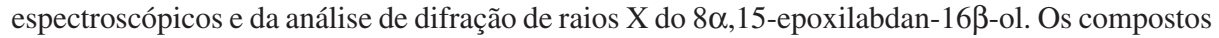
16-acetóxi- $8 \alpha, 15$-epoxilabdano, $8 \alpha, 15$-epoxi-16-norlabdan-13-ona e $8 \alpha, 15$-epoxilabdan-16 $\beta$-ol não apresentam genotoxicidade e mutagenicidade, as quais foram avaliadas usando o teste dos micronúcleos e o teste de Ames, respetivamente. A citotoxicidade dos mesmos compostos foi avaliada usando o teste do MTT sendo o $8 \alpha, 15$-epoxilabdan-16 $\beta$-ol o mais citotóxico de todos os compostos analisados. Foram também avaliadas a capacidade antioxidante, o valor peróxido e o conteúdo em fenóis totais de extratos de E. viscosa.

Three new labdanes with $8 \alpha, 15$-epoxy ring [methyl $8 \alpha, 15$-epoxylabdan-16 $\beta$-oate, $8 \alpha, 15$-epoxylabdan-16 $\beta$-ol and $8 \alpha, 15$-epoxy-16-norlabdan-13 $\beta$-ol] and five known compounds

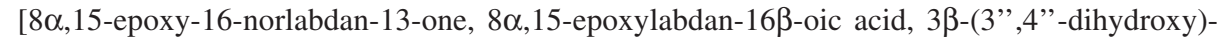
(E)-cinnamoyloxylup-20(29)-ene, 3-(2',3',4',6'-tetra- $O$-acetyl- $\beta$-D-glucopyranosyloxy)$\beta$-sitosterol and 16-acetoxy-8 $\alpha, 15$-epoxylabdane] were isolated from toluene and dichloromethane extracts of aerial parts of Eragrostis viscosa. The structures of all the compounds were established based on their spectroscopic data and X-ray diffraction analysis of $8 \alpha, 15$-epoxylabdan-16 $\beta$-ol. It was also studied the genotoxicity of E. viscosa, particularly compounds 16 -acetoxy- $8 \alpha, 15$ epoxylabdane, $8 \alpha, 15$-epoxy-16-norlabdan-13-one and $8 \alpha, 15$-epoxilabdan-16 $\beta$-ol, using a cytokinesis-block micronucleus assay and the Ames test to assess mutagenicity. Both assays were negative. Cytotoxicity was also analyzed using an MTT assay, and $8 \alpha, 15$-epoxy-16 $\beta$-ol was shown to be the most cytotoxic of the compounds tested. E. viscosa extracts were also tested to determine their antioxidant capacities, peroxide values and total phenolic contents.

Keywords: Eragrostis viscosa, 8 $\alpha, 15$-epoxylabdanes, mutagenic activity, cytotoxic activity, genotoxicity

*e-mail: disabel@ubi.pt 


\section{Introduction}

Eragrostis species (Poaceae, Eragrostoideae tribe) are well known for their nutritive value. ${ }^{1,2}$ Nevertheless, cattle refuse to eat Eragrostis viscosa (Retz.) Trin., which is used in folk medicine as a poison against snakes.

Some of the most important fodders from this genus include E. nigra, E. tef and E. curvula. However, studies conducted on these plants have primarily addressed their nutritive values, not their chemical compositions. ${ }^{1,3,4}$ In our research on Angolan plants, ${ }^{5-7}$ our group previously reported the isolation of labdanes containing a novel 8,15 -epoxide. ${ }^{6}$ Now, it is reported the isolation of new $8 \alpha, 15$-epoxylabdanes 6 and 7 along with known compounds 16-acetoxy-8 $\alpha, 15$-epoxylabdane (2), ${ }^{6} 8 \alpha, 15$-epoxy16-norlabdan-13-one $(3)^{6}$ and $8 \alpha, 15$-epoxylabdan$16 \beta$-oic acid (4) (Figure 1). ${ }^{6}$ These compounds were isolated by a maceration of the aerial parts of E. viscosa at room temperature in dichloromethane, and were characterized by the techniques Fourier transform IR spectroscopy, ${ }^{1} \mathrm{H}$ and ${ }^{13} \mathrm{C}$ nuclear magnetic resonance (NMR), 2D NMR, electron ionization mass spectrometry (HREIMS) and X-ray diffractometry (XRD) of 6. A new $8 \alpha, 15$-epoxylabdane $\mathbf{1}$ was isolated from the toluene extract along with the known compounds $8 \alpha, 15$-epoxy16-norlaban-13-one (3), ${ }^{6} 8 \alpha, 15$-epoxylabdan-16 $\beta$-oic acid (4), ${ }^{6} 3 \beta$-(3", 4"'-dihydroxy)-(E)-cinnamoyloxylup20(29)-ene $(5)^{8}$ and 3-(2',3',4',6'-tetra- $O$-acetyl$\beta$-D-glucopyranosyloxy)- $\beta$-sitosterol (8) (Figure 1$).{ }^{8}$ The known compounds were identified on the basis of their spectral data and comparison with appropriate reported data.
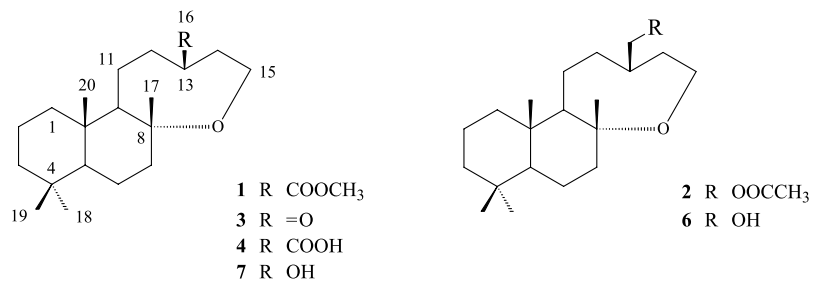

Figure 1. Chemical structures of the isolated compounds.

Our group tested the genotoxicity of E. viscosa, particularly compounds $\mathbf{2}, \mathbf{3}$ and $\mathbf{6}$, using an MTT (3-(4,5-dimethylthiazol-2-yl)-2,5-diphenyl tetrazolium bromide) assay as a biomarker of cytotoxicity, the cytokinesis-block micronucleus (MN) assay in hamster V79 cells as a biomarker of cytogenetic damage, and the Ames test to detect potential mutagenic damage was tested. The antioxidant capacities, peroxide values and total phenolic contents of some extracts of $E$. viscosa are also presented.

\section{Experimental}

\section{General experimental procedures}

Optical rotations were obtained using a Bellingham + Stanley Ltd ADP 220 polarimeter. HREIMS measurements were conducted on a VG Autospec $\mathrm{M}$ and recorded at $70 \mathrm{eV}$. IR spectra were measured in a Unicam Mattson 5000 FTIR. X-ray diffraction analyses were performed in a Bruker SMART CCD 1000 with Mo $\mathrm{K}_{\alpha}$ radiation $(\lambda=0.71073 \AA)$. NMR spectra were recorded in a Bruker Avance II at $600 \mathrm{MHz}\left({ }^{1} \mathrm{H} \mathrm{NMR}\right)$ or $150.9 \mathrm{MHz}\left({ }^{13} \mathrm{C} \mathrm{NMR}\right)$ in $\mathrm{CDCl}_{3}$. Chemical shifts $(\delta)$ are given in ppm and are referenced to the residual $\mathrm{CHCl}_{3}$, using $7.26 \mathrm{ppm}$ for the ${ }^{1} \mathrm{H}$ peak and $77.0 \mathrm{ppm}$ for the ${ }^{13} \mathrm{C}$ peak. Two-dimensional experiments were performed with standard Bruker software. Column chromatography was performed on silica gel 60 (70-230 mesh, Merck, Darmstadt, Germany) using a hexane-EtOAc gradient.

Plant material

The aerial parts of E. viscosa were collected in the outskirts of Lubango (Huíla), Angola, in July 2003 and were identified by the staff of the Lubango Herbarium. A voucher specimen (No. 3666) was deposited at the Lubango Herbarium, Angola.

\section{Extraction and isolation}

The dried aerial parts (400 g) that were collected in 2003 were successively extracted with hexane (hexane 2 extract), toluene (producing $8.4 \mathrm{~g}$ of toluene extract) and ethyl acetate in a Soxhlet apparatus for $24 \mathrm{~h}$. The hexane 1 extract was obtained from plants collected in $2001 .^{6} \mathrm{~A}$ total of $200 \mathrm{~g}$ of the dried aerial parts collected in 2003 was macerated in dichloromethane for one week to yield $30 \mathrm{~g}$ of crude extract. The dichloromethane crude extract afforded $18 \mathrm{~g}$ of material after being dewaxed with methanol. The toluene extract was separated into 5 fractions (hexane/EtOAc 95:5, 8:2, 6:4, 1:1 and ethyl acetate). The fraction eluted with 95:5 hexane/EtOAc was separated on a silica gel column with a hexane/EtOAc gradient to yield methyl $8 \alpha, 15$-epoxylabdan-16 6 -oate (1) $(8 \mathrm{mg})$ and $8 \alpha, 15$-epoxy-16-norladban-13-one (3) (20 mg). The fraction eluted with 8:2 hexane/EtOAc was separated on a silica gel column with a hexane/EtOAc gradient to yield $8 \alpha, 15$-epoxylabdan-16 $\beta$-oic acid (4) (70 mg). The fraction eluted with 1:1 hexane/EtOAc was separated on a silica gel column with a hexane/EtOAc gradient to yield $3 \beta-(3$ ", 4"'-dihydroxy)- $(E)$-cinnamoyloxylup- 
20(29)-ene (5) (12 mg). The fraction eluted with EtOAc was separated on a silica gel column with a hexane/EtOAc gradient to yield 3-(2',3',4',6'-tetra$O$-acetyl- $\beta$-D-glucopyranosyloxy)- $\beta$-sitosterol (8) $(35 \mathrm{mg})$. A sample of the dichloromethane extract $(8.5 \mathrm{~g})$, obtained from maceration was separated into 7 fractions (hexane/EtOAc 95:5, 9:1, 8:2, 7:3, 6:4, 1:1 and ethyl acetate). The fraction eluted with 8:2 hexane/EtOAc was separated on a silica gel column with a hexane/EtOAc gradient to yield 16-acetoxy- $8 \alpha, 15$-epoxylabdane (2) $(470 \mathrm{mg})$ and $8 \alpha, 15$-epoxy-16-norlabdan-13-one (3) (17 mg). The fraction eluted with 6:4 hexane/EtOAc was separated on a silica gel column with a hexane/EtOAc gradient to yield $8 \alpha, 15$-epoxylabdan-16 $\beta$-oic acid (4) $(720 \mathrm{mg}$ ). The fraction eluted with 1:1 hexane/EtOAc was separated on a silica gel column with a hexane/EtOAc gradient to yield

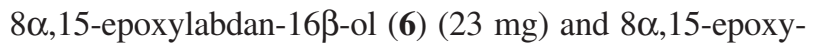
16-norlabdan-13ß-ol (7) (55 mg).
Methyl $8 \alpha, 15$-epoxylabdan-16 $\beta$-oate (1)

Colorless oil; $[\alpha]_{\mathrm{D}}^{25}+55.2^{\circ}\left(c 0.12, \mathrm{CHCl}_{3}\right) ; \mathrm{IR} v_{\max } / \mathrm{cm}^{-1}$ 2926, 2868, 1738, 1452, 1385, 1271, 1165, 1084, 756; ${ }^{1} \mathrm{H}$ NMR $\left(\mathrm{CDCl}_{3}, 600 \mathrm{MHz}\right)$ and ${ }^{13} \mathrm{C} \mathrm{NMR}\left(\mathrm{CDCl}_{3}\right.$, 150.9 MHz): see Table 1; HR-TOF-EIMS (pos.) $\mathrm{m} / \mathrm{z}$ $336.2664[\mathrm{M}]^{+}$(calcd. for $\mathrm{C}_{21} \mathrm{H}_{36} \mathrm{O}_{3}, 336.2664$ ).

\section{8 $\alpha, 15$-Epoxylabdan-16 $\beta$-ol (6)}

Colorless oil; $[\alpha]_{\mathrm{D}}^{25}+21.2^{\circ}\left(c 0.5, \mathrm{CHCl}_{3}\right) ; \mathrm{IR} v_{\max } / \mathrm{cm}^{-1}$ 3422, 2940, 1461, 1388, 1076, 1024, 757; ${ }^{1} \mathrm{H}$ NMR $\left(\mathrm{CDCl}_{3}\right.$, $600 \mathrm{MHz})$ and ${ }^{13} \mathrm{C}$ NMR $\left(\mathrm{CDCl}_{3}, 150.9 \mathrm{MHz}\right)$ : see Table 1; HR-TOF-EIMS (pos.) $\mathrm{m} / \mathrm{z} 308.2714[\mathrm{M}]^{+}$(calcd. for $\mathrm{C}_{20} \mathrm{H}_{36} \mathrm{O}_{2}, 308.2715$ ).

\section{$8 \alpha, 15$-Epoxy-16-norlabdan-13ß-ol (7)}

Colorless oil; $[\alpha]_{\mathrm{D}}^{25}+25.2^{\circ}\left(c 0.16, \mathrm{CHCl}_{3}\right)$; IR $v_{\max } / \mathrm{cm}^{-1}$ : $3426,2936,1462,1389,1072,756 \mathrm{~cm}^{-1} ;{ }^{1} \mathrm{H} \mathrm{NMR}\left(\mathrm{CDCl}_{3}\right.$, $600 \mathrm{MHz})$ and ${ }^{13} \mathrm{C} \mathrm{NMR}\left(\mathrm{CDCl}_{3}, 150.9 \mathrm{MHz}\right)$ : see Table 1;

Table 1. ${ }^{1} \mathrm{H}$ and ${ }^{13} \mathrm{C}$ NMR data and HMBC correlations of compounds $\mathbf{1}$ and $\mathbf{6}^{\mathrm{a}}$

\begin{tabular}{|c|c|c|c|c|c|c|}
\hline \multirow{2}{*}{ Position } & \multicolumn{3}{|c|}{1} & \multicolumn{3}{|c|}{6} \\
\hline & $\delta{ }^{13} \mathrm{C}$ & $\delta^{1} \mathrm{H}(\mathrm{mult}, \mathrm{nH}, J / \mathrm{Hz})$ & HMBC & $\delta^{13} \mathrm{C}$ & $\delta^{1} \mathrm{H}($ mult, $\mathrm{nH}, J / \mathrm{Hz})$ & HMBC \\
\hline 1 & 40.7 & $\begin{array}{c}0.91(\mathrm{dd}, 1 \mathrm{H}, 12.8,3.7) \\
1.75(\mathrm{~m}, 1 \mathrm{H})\end{array}$ & $2,3,10,20$ & 40.0 & $\begin{array}{l}0.88(\mathrm{~m}, 1 \mathrm{H}) \\
1.78(\mathrm{~m}, 1 \mathrm{H})\end{array}$ & $2,3,5,10,20$ \\
\hline 2 & 18.7 & $\begin{array}{l}1.42(\mathrm{~m}, 1 \mathrm{H}) \\
1.60(\mathrm{~m}, 1 \mathrm{H})\end{array}$ & $1,3,4,10$ & 18.6 & $\begin{array}{l}1.30(\mathrm{~m}, 1 \mathrm{H}) \\
1.57(\mathrm{~m}, 1 \mathrm{H})\end{array}$ & $1,3,4,10$ \\
\hline 3 & 41.9 & $\begin{array}{l}1.13(\mathrm{td}, 1 \mathrm{H}, 13.2,4.0) \\
1.38(\mathrm{dt}, 1 \mathrm{H}, 13.2,3.6)\end{array}$ & $1,2,4,5,18,19$ & 42.2 & $\begin{array}{c}1.13(\mathrm{dd}, 1 \mathrm{H}, 14.0,4.0) \\
1.39(\mathrm{~m}, 1 \mathrm{H})\end{array}$ & $1,2,4,5,18,19$ \\
\hline 4 & 33.3 & & & 33.5 & & \\
\hline 5 & 56.4 & $0.85(\mathrm{dd}, 1 \mathrm{H}, 5.2,3.3)$ & $4,6,10,18,19,20$ & 56.5 & $0.82(\mathrm{~m}, 1 \mathrm{H})$ & $4,6,7,9,18,19,20$ \\
\hline 6 & 20.1 & $1.65(\mathrm{~m}, 2 \mathrm{H})$ & $5,7,8$ & 20.5 & $\begin{array}{l}1.23(\mathrm{~m}, 1 \mathrm{H}) \\
1.69(\mathrm{~m}, 1 \mathrm{H})\end{array}$ & $4,5,7,8,10,18$ \\
\hline 7 & 38.2 & $\begin{array}{c}1.52(\mathrm{ddd}, 1 \mathrm{H}, 10.0,7.3,3.9) \\
1.75(\mathrm{~m}, 1 \mathrm{H})\end{array}$ & $5,6,8,9,17$ & 37.1 & $\begin{array}{l}1.49(\mathrm{~m}, 1 \mathrm{H}) \\
1.78(\mathrm{~m}, 1 \mathrm{H})\end{array}$ & $5,6,8,9,17$ \\
\hline 8 & 78.5 & & & 78.5 & & \\
\hline 9 & 50.2 & $1.45(\mathrm{~m}, 1 \mathrm{H})$ & $1,5,8,11,12,17,20$ & 57.1 & $1.52(\mathrm{~m}, 1 \mathrm{H})$ & $5,7,8,10,11,12,17,20$ \\
\hline 10 & 38.5 & & & 39.4 & & \\
\hline 11 & 22.8 & $\begin{array}{l}1.46(\mathrm{~m}, 1 \mathrm{H}) \\
1.66(\mathrm{~m}, 1 \mathrm{H})\end{array}$ & $8,9,10,12,13$ & 24.2 & $\begin{array}{c}1.18(\mathrm{~m}, 1 \mathrm{H}) \\
1.62(\mathrm{ddd}, 1 \mathrm{H}, 14.4,11.0,5.6)\end{array}$ & $8,9,10,12,13$ \\
\hline 12 & 29.5 & $\begin{array}{c}1.92(\mathrm{~m}, 1 \mathrm{H}) \\
2.02(\mathrm{ddt}, 1 \mathrm{H}, 8.6,5.0,4.1)\end{array}$ & $9,11,13,14,16$ & 33.5 & $\begin{array}{c}0.86(\mathrm{~m}, 1 \mathrm{H}) \\
1.93(\mathrm{dd}, 1 \mathrm{H}, 13.8,7.2)\end{array}$ & $9,11,13,14,16$ \\
\hline 13 & 43.5 & $2.46(\mathrm{~m}, 1 \mathrm{H})$ & 12,14 & 40.7 & $1.83(\mathrm{~m}, 1 \mathrm{H})$ & $12,15,16$ \\
\hline 14 & 33.5 & $1.78(\mathrm{~m}, 2 \mathrm{H})$ & $12,13,14$ & 32.8 & $\begin{array}{l}1.32(\mathrm{~m}, 1 \mathrm{H}) \\
1.79(\mathrm{~m}, 1 \mathrm{H})\end{array}$ & $12,13,15,16$ \\
\hline 15 & 60.1 & $\begin{array}{c}3.65(\mathrm{~m}, 1 \mathrm{H})^{\mathrm{b}} \\
3.71(\mathrm{td}, 1 \mathrm{H}, 13.1,2.7)\end{array}$ & $8,13,14$ & 57.4 & $\begin{array}{c}3.47(\mathrm{~m}, 1 \mathrm{H}) \\
3.81(\mathrm{ddd}, 1 \mathrm{H}, 13.6,10.7,6.7)\end{array}$ & $8,13,14$ \\
\hline 16 & 177.5 & & & 68.8 & $\begin{array}{l}3.41(\mathrm{dd}, 1 \mathrm{H}, 10.4,6.5) \\
3.43(\mathrm{dd}, 1 \mathrm{H}, 10.4,6.2)\end{array}$ & $12,13,14$ \\
\hline 17 & 23.5 & $1.15(\mathrm{~s}, 3 \mathrm{H})$ & $7,8,9$ & 24.3 & $1.16(\mathrm{~s}, 3 \mathrm{H})$ & $7,8,9$ \\
\hline 18 & 33.4 & $0.88(\mathrm{~s}, 3 \mathrm{H})$ & $3,4,5,19$ & 33.4 & $0.88(\mathrm{~s}, 3 \mathrm{H})$ & $3,4,5,19$ \\
\hline 19 & 21.6 & $0.79(\mathrm{~s}, 3 \mathrm{H})$ & $3,4,5,18$ & 21.4 & $0.79(\mathrm{~s}, 3 \mathrm{H})$ & $3,4,5,18$ \\
\hline 20 & 15.5 & $0.83(\mathrm{~s}, 3 \mathrm{H})$ & $1,5,9,10$ & 15.8 & $0.76(\mathrm{~s}, 3 \mathrm{H})$ & $1,5,9,10$ \\
\hline $16-\mathrm{COOCH}_{3}$ & 51.7 & $3.65(\mathrm{~s}, 3 \mathrm{H})^{\mathrm{b}}$ & 16 & & & \\
\hline
\end{tabular}

${ }^{\text {a }}$ Spectra were recorded at 600 and $150.9 \mathrm{MHz}$ for ${ }^{1} \mathrm{H}$ and ${ }^{13} \mathrm{C}$ NMR, respectively; 2D NMR experiments recorded in accordance; coupling constants are in parenthesis; ${ }^{\mathrm{b}}$ overlapped signal. 
HR-TOF-EIMS (pos.) $\mathrm{m} / z$ 294.2561 [M] ${ }^{+}$(calcd. for $\mathrm{C}_{19} \mathrm{H}_{34} \mathrm{O}_{2}$, 294.2559).

\section{Hydrolysis of 2}

First, $15 \mathrm{~mL}$ of a $4 \%$ solution of $\mathrm{KOH} / \mathrm{MeOH}$ were added to $150 \mathrm{mg}$ of $\mathbf{2}$. The mixture was left for $2 \mathrm{~h}$ at room temperature, diluted with water $(15 \mathrm{~mL})$ and left for an additional $2 \mathrm{~h}$ at room temperature. $\mathrm{MeOH}$ was evaporated under vacuum and the aqueous solution was extracted with $\mathrm{Et}_{2} \mathrm{O}$. The organic layer was washed with $\mathrm{H}_{2} \mathrm{O}$ until a pH 7 was obtained, dried over $\mathrm{Na}_{2} \mathrm{SO}_{4}$, filtered and evaporated under vacuum to yield $\mathbf{6}(111 \mathrm{mg})$, whose NMR spectra and optical rotation data were identical to those of the natural alcohol.

\section{Determination of total phenolic contents}

The total phenolic contents of extracts from E. viscosa were determined using the Folin-Ciocalteu reagent according to the method previously reported by Matkowski and Piotrowska ${ }^{9}$ with minor modifications. A total of $400 \mu \mathrm{L}$ of a $0.05 \mathrm{mg} \mathrm{L}^{-1}$ methanolic extract solution was reacted with $2 \mathrm{~mL}$ of the Folin-Ciocalteu reagent $\left(0.2 \mathrm{~mol} \mathrm{~L}^{-1}\right)$ for $8 \mathrm{~min}$ at room temperature. The reaction was then neutralized with $7.5 \%$ sodium carbonate and allowed to stand for $90 \mathrm{~min}$ at room temperature. Absorbance was measured at $765 \mathrm{~nm}$ with a Pharmacia Biotech spectrophotometer Ultrospec U/V 3000. Quantification was done based on a standard curve with gallic acid. Results were expressed as mg of gallic acid equivalents (GAE) per $\mathrm{g}$ of dry extract. The absorbance versus concentration curve is described by the equation $y=0.012 x-0.018\left(\mathrm{R}^{2}=0.9922\right)$, in which $y$ : absorbance and $x$ : concentration.

\section{ABTS assay}

The assay was performed with a Pharmacia Biotech spectrophotometer Ultrospec U/V 3000 using the ABTS (total antioxidant capacity) method described elsewhere ${ }^{10}$ with minor modifications. ABTS $^{\circ+}$ radical cations were generated by reacting $7 \mathrm{mmol} \mathrm{L}^{-1}$ ABTS with $140 \mathrm{mmol} \mathrm{L}^{-1}$ potassium persulfate. The reaction mixture was allowed to stand in the dark for $16 \mathrm{~h}$ at room temperature and was used within 1 day. The ABTS ${ }^{\circ+}$ solution was diluted with $50 \%$ ethanol to an absorbance of $0.700 \pm 0.050$ at $734 \mathrm{~nm}$. Measurements were taken on a mixture of $3 \mathrm{~mL}$ of the $\mathrm{ABTS}^{*+}$ solution and $30 \mu \mathrm{L}$ of the $0.05 \mathrm{mg} \mathrm{L}^{-1}$ methanolic extract solutions over a period of 15 min (reading times $1 \mathrm{~s}, 5 \mathrm{~s}, 1,3,5,10$ and
$15 \mathrm{~min}$ ), and each set of measurements was taken at least three times and in triplicate. Inhibition (I, \%) was calculated as follows:

$$
\mathrm{I}=100\left(\frac{\mathrm{A}_{0}-\mathrm{A}_{\mathrm{t}}}{\mathrm{A}_{0}}\right)
$$

where $\mathrm{A}_{0}$ is the absorbance of the control (methanol), and $\mathrm{A}_{\mathrm{t}}$ is the absorbance of the mixture. A $0.05 \mathrm{mg} \mathrm{L}^{-1}$ Trolox $^{\circledR}$ solution was used as a reference standard.

\section{DPPH assay}

The DPPH (1,1-diphenyl-2-picrylhydrazyl) radical scavenging assay was performed according to the method reported by Villaño et al. ${ }^{11}$ with some modifications. Briefly, $200 \mu \mathrm{L}$ of either the $0.05 \mathrm{mg} \mathrm{L}^{-1}$ methanolic extract solutions or methanol (control) were added to $2.7 \mathrm{~mL}$ of a $40 \mu \mathrm{mol} \mathrm{L}^{-1}$ solution of DPPH in methanol. Mixtures were shaken vigorously, and the absorbance was measured using a Pharmacia Biotech spectrophotometer Ultrospec U/V 3000 over a period of $15 \mathrm{~min}$ (reading times $1 \mathrm{~s}, 5 \mathrm{~s}, 1,3,5,10$ and $15 \mathrm{~min}$ ). Antiradical activity was expressed as an inhibition percentage (I, \%) and calculated using the equation (1).

\section{Oil oxidation}

To determine the peroxide values, $20 \mathrm{~mL}$ of sunflower oil and $2 \mathrm{~mL}$ of the extracts $\left(0.01 \mathrm{~g} \mathrm{~mL}^{-1}\right)$ were oxidized by heating at $80^{\circ} \mathrm{C}$ for eight days. The control sample was made from $20 \mathrm{~mL}$ of sunflower oil and $2 \mathrm{~mL}$ of methanol.

\section{Peroxide value assay}

The peroxide value assay was conducted as described in Method Cd 8-53 of the AOCS Official Methods and Recommended Practices of the American Oil Chemists' Society ${ }^{12}$ with minor modifications. Briefly, $2.5 \mathrm{~g}$ of sample were swirled in $15 \mathrm{~mL}$ of a 3:2 acetic acid-chloroform solution until dissolved. At this point, $0.25 \mathrm{~mL}$ of a saturated KI solution was added, the mixture was shaken for $1 \mathrm{~min}$ and an additional $15 \mathrm{~mL}$ of distilled water were added. The mixture was then titrated with $0.1 \mathrm{~mol} \mathrm{~L}^{-1}$ sodium thiosulfate standardized with a fresh solution of $\mathrm{I}_{3}^{-}$prepared from $\mathrm{KIO}_{3}$ plus $\mathrm{KI}$.

\section{MTT cytotoxicity assay}

The MTT assay was conducted in V79 Chinese hamster cells. Approximately $10^{4}$ cells were grown at $37^{\circ} \mathrm{C}$ in a $5 \%$ $\mathrm{CO}_{2}$ atmosphere for $24 \mathrm{~h}$ in 96 -well plates using $200 \mu \mathrm{L}$ 
of Ham's F-10 medium supplemented with $10 \%$ newborn calf serum and $1 \%$ penicillin/streptomycin solution. Various doses of compounds $\mathbf{2}, \mathbf{3}$ and $\mathbf{6}$ (25, 50 and $250 \mu \mathrm{g}$ per well) were added, and the cells were incubated for $3 \mathrm{~h}$. The medium was removed, and the cells were incubated for an additional $3 \mathrm{~h}$ with MTT $\left(0.5 \mathrm{mg} \mathrm{mL}^{-1}\right)$. The cells were washed carefully with phosphate buffered saline (PBS), then $200 \mu \mathrm{L}$ of DMSO (dimethyl sulfoxide) was added to each well. The absorbance of the converted dye was measured at $595 \mathrm{~nm}$ in a Zenith 3100 microplate reader. Cytotoxicity was assessed by comparing the absorbance values of the treated cells with those of the control cells. Three independent experiments were performed.

\section{Ames assay}

Mutagenicity testing was conducted by the plate incorporation assay described by Maron and $\mathrm{Ames}^{13}$ using Salmonella typhimurium strains TA 98, TA 100 and TA 102 in the presence or absence of S9 mix. ${ }^{13}$ At least two independent experiments were performed for each assay.

\section{Cytokinesis-block micronucleus assay (CBMN)}

Approximately $5 \times 10^{5}$ V79 Chinese hamster cells were cultured for $24 \mathrm{~h}$ in $25 \mathrm{~cm}^{2}$ culture flasks and then exposed to compounds $\mathbf{2}, \mathbf{3}$ and $\mathbf{6}$ at concentrations of 10 , 25 or $50 \mu \mathrm{g} \mathrm{mL}^{-1}$. Cyclophosphamide $\left(2.0 \mu \mathrm{g} \mathrm{mL}^{-1}\right)$ and mitomycin $\mathrm{C}\left(2.5 \mu \mathrm{g} \mathrm{mL}^{-1}\right)$ were used as positive controls for the experiments with and without $\mathrm{S} 9 \mathrm{mix}$, respectively. At $24 \mathrm{~h}$ after the genotoxic treatment, the cells were washed with fresh culture medium, and cytochalasin-B (Cyt-B) was added to produce a final concentration of $4.5 \mu \mathrm{g} \mathrm{mL}^{-1}$. The cells were incubated for an additional $16 \mathrm{~h}$, harvested by trypsinization, rinsed and submitted to a mild hypotonic treatment as described elsewhere. ${ }^{14}$ The centrifuged cells were placed onto dry slides, and smears were made. After air-drying, the slides were fixed with cold methanol for $30 \mathrm{~min}$. One day later, the slides were stained with Giemsa $\left(4 \%(\mathrm{v} / \mathrm{v})\right.$ in $0.01 \mathrm{~mol} \mathrm{~L}^{-1}$ sodium phosphate buffer, $\mathrm{pH}$ 6.8) for $10 \mathrm{~min}$. For each experimental point, 1000 binucleate V79 cells (BN) with well-preserved cytoplasms were scored. Micronuclei were identified under a light microscope using a magnification of $1250 \times$ according to the criteria proposed by Caria et al..$^{15}$ It was evaluated the $\mathrm{MN} / \mathrm{BN}$ value, which represents the average number of micronuclei per binucleated cell, and the percentage MNBN, which represents the fraction of cytokinesis-blocked (binucleated) cells with micronuclei, regardless of the number of micronuclei per $\mathrm{BN}$ cell. ${ }^{16}$ The decrease in cell proliferation was also measured in these assays by determining the frequency of binucleate cells $(\mathrm{BN}, \%)$. For this index, the number of nuclei in 1000 cells with well-preserved cytoplasms was determined at a magnification of 500x. At least two independent experiments were performed for each assay.

\section{Statistical analysis}

All the values presented throughout the text and tables correspond to mean values and respective standard deviations (SD) from all experiments. The statistical analysis was carried out with student's $t$-test. All analyses were performed with the SPSS statistical package (version 17; Chicago, USA).

\section{Crystal data for 6}

Monoclinic crystals of $\mathbf{6}$ were formed by a slow crystallization from 4:1 hexane/EtOAc. Operations were performed on a Bruker SMART CCD 1000 diffractometer using graphite-monochromated $\mathrm{Mo}_{\alpha}$ radiation at 293(2) K with 5287 reflections obtained (2175 independent, $\left.R_{\text {int }}=0.0384\right)$, measured at $\theta_{\text {max }}=28.02^{\circ}$ from a crystal of size $0.48 \times 0.30 \times 0.18 \mathrm{~mm}^{3}\left(\mathrm{C}_{20} \mathrm{H}_{36} \mathrm{O}_{2}\right)$, yielding the following parameters: $a=9.5115(18), b=7.0325(13), c=14.496(3)$, $\alpha=90^{\circ}, \beta=104.630(4)^{\circ}, \gamma=90^{\circ}, V=938.2(3) \AA^{3}$, $d_{\text {calcd }}=1.092 \mathrm{mg} \mathrm{m}^{-3}, Z=2$, and spatial group P2(1). The structure was solved by a direct method and refined anisotropically to give $\mathrm{R}_{1}=0.0619$ and $\mathrm{wR}_{2}=0.01591$ for $2175[\mathrm{R}$ (int) $=0.0384]$ independently observed reflections $\left(\mathrm{I}>2 \sigma(\mathrm{I}), \theta \leq 25^{\circ}\right)$ with a goodness-of-fit $=0.989$.

\section{Results and Discussion}

Compound 1 was obtained as a colorless oil with an $[\alpha]_{D}^{25}$ value of $+55.2^{\circ}\left(c 0.012, \mathrm{CHCl}_{3}\right)$. The HR-TOF-EIMS analysis of 1 revealed a molecular ion peak at $m / z 336.2664$ that corresponds to a molecular formula of $\mathrm{C}_{21} \mathrm{H}_{36} \mathrm{O}_{3}$ (calculated at 336.2664), which includes four degrees of unsaturation. The IR spectrum showed the presence of a methyl ester $\left(1738\right.$ and $\left.1385 \mathrm{~cm}^{-1}\right)$ and an ether $\left(1084 \mathrm{~cm}^{-1}\right)$.

The ${ }^{1} \mathrm{H}$ NMR spectrum of compound $\mathbf{1}$ showed signals corresponding to four tertiary methyl groups at $\delta_{\mathrm{H}} 1.15$, $0.88,0.83$ and $0.79(\mathrm{~s}$, each $3 \mathrm{H})$, a methoxy group at $\delta_{\mathrm{H}}$ $3.65(\mathrm{~s}, 3 \mathrm{H})$ and one diastereotopic oxymethylene at $\delta_{\mathrm{H}}$ $3.71(\mathrm{td}, 1 \mathrm{H}, J 13.1,2.7 \mathrm{~Hz})$ and $3.65(\mathrm{~m}, 1 \mathrm{H}, \mathrm{H}-15)$ that had COSY (correlation spectroscopy) correlations with H-14 and HMBC (heteronuclear multiple bond correlation) correlations from $\mathrm{H}-15$ to $\mathrm{C}-8$ and $\mathrm{C}-14$.

The ${ }^{13} \mathrm{C}$ NMR spectrum showed 21 carbons, which were interpreted as five methyls (one as part of a methyl 
ester), nine methylenes, three methines and four quaternary carbons (one as part of a methyl ester) from the DEPT (distortionless enhancement by polarization transfer) spectrum. The ${ }^{13} \mathrm{C}$ NMR chemical shifts of four methyl groups $\left(\delta_{\mathrm{C}} 33.4,23.5,21.6\right.$ and 15.5), one methylene $\left(\delta_{\mathrm{C}} 60.1\right)$, three methines $\left(\delta_{\mathrm{C}} 56.4,50.2\right.$ and 43.5$)$ and three quaternary carbons $\left(\delta_{\mathrm{C}} 78.5,38.5\right.$ and 33.3$)$ were very similar to those from an epoxylabdane scaffold. The other ${ }^{13} \mathrm{C}$ and ${ }^{1} \mathrm{H}$ NMR, ${ }^{1} \mathrm{H}-{ }^{1} \mathrm{H}$ COSY, HSQC (heteronuclear single quantum coherence) and HMBC data (Table 1, Figure 2) were also consistent with such structure. ${ }^{17}$ The H-15/C-8 HMBC correlation, the presence of an ether $\left(1067 \mathrm{~cm}^{-1}\right)$ and the lack of an $\mathrm{OH}$ absorption in the IR spectrum, coupled with the four degrees of unsaturation, confirmed the presence of a $8 \alpha, 15$-epoxylabdane ${ }^{6}$ in which C-16 is part of a methyl ester $\left(\delta_{\mathrm{C}} 177.5,51.7\right)$. The NOESY (nuclear Overhauser effect spectroscopy) correlations ( $\mathrm{H}-5 / \mathrm{Me}-18$, $\mathrm{H}-9$ and $\mathrm{H}-9 / \mathrm{H}-13$ ) indicated that H-5, H-9, H-13 and Me-18 were all on the $\alpha$ face of the molecule, which means that C-9 and C-16 were $\beta$ oriented (Figure 3). Additional NOESY correlations (Me-19/Me-17, Me-20) suggested that these methyl groups were also $\beta$ oriented (Figure 3). Thus the structure of compound $\mathbf{1}$ was established as methyl $8 \alpha, 15$-epoxylabdan-16 $\beta$-oate (Figure 1).
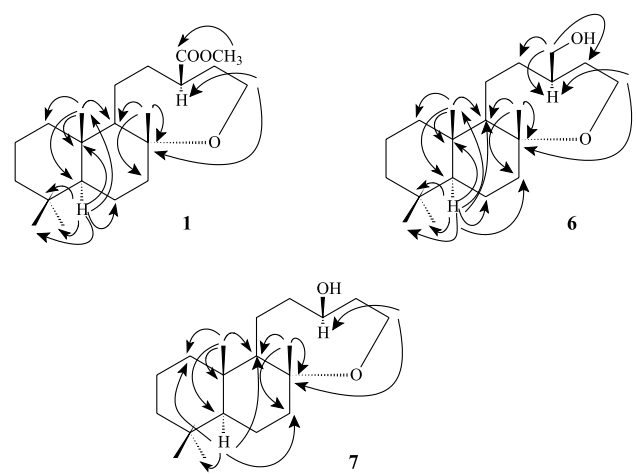

Figure 2. Key HMBC correlations of 1, 6 and 7.
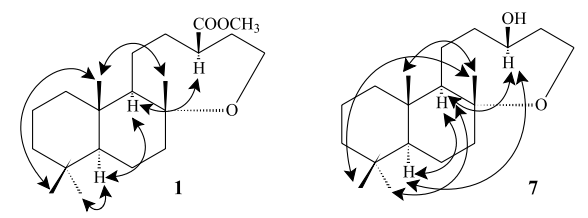

Figure 3. Key NOESY correlations of $\mathbf{1}$ and $\mathbf{7}$.

Compound 6 was obtained as a colorless oil with an $[\alpha]_{D}^{25}$ value of $+21.2^{\circ}\left(c 0.50, \mathrm{CHCl}_{3}\right)$. The HR-TOF-EIMS analysis showed a molecular ion peak at $\mathrm{m} / \mathrm{z}, 308.2714$ (calculated at 308.2715), suggesting a tricyclic structure with a molecular formula of $\mathrm{C}_{20} \mathrm{H}_{36} \mathrm{O}_{2}$. The IR spectrum revealed bands corresponding to a hydroxyl group $\left(3420 \mathrm{~cm}^{-1}\right)$ and an ether $\left(1026 \mathrm{~cm}^{-1}\right)$.
The spectral $\left({ }^{1} \mathrm{H}\right.$ and ${ }^{13} \mathrm{C}$ NMR $)$ characteristics of compound $\mathbf{6}$ were very similar to those of $\mathbf{1}$, suggesting that $\mathbf{6}$ is a derivative of $\mathbf{1}$. Differences in the ${ }^{1} \mathrm{H}$ NMR spectrum of $\mathbf{6}$ include the absence of the methyl ester group and the presence of a hydroxyl group. The ${ }^{1} \mathrm{H}$ NMR spectrum of the compound showed signals for four methyl groups at $\delta_{\mathrm{H}} 1.16,0.88,0.79$, and $0.76(\mathrm{each} 3 \mathrm{H}, \mathrm{s})$ and one diastereotopic oxymethylene at $\delta_{\mathrm{H}} 3.81$ (ddd, $1 \mathrm{H}, J$ 13.6, $10.7,6.7 \mathrm{~Hz})$ and $3.47(\mathrm{~m}, 1 \mathrm{H}, \mathrm{H}-15)$ that presented COSY correlations with $\mathrm{H}-14$. The HMBC correlations (H-15/C-8, $\mathrm{C}-14)$ were in good agreement with the presence of an 8,15 -epoxy ring, and another oxymethylene at $\delta_{\mathrm{H}} 3.43(\mathrm{dd}$, $1 \mathrm{H}, J 10.4,6.2 \mathrm{~Hz})$ and $3.41(\mathrm{dd}, 1 \mathrm{H}, J 10.4,6.5 \mathrm{~Hz})$ showed a COSY correlation with $\mathrm{H}-13$ and HMBC correlations (H-16/C-13, C-12, C-14) that established position 16 as the new oxymethylene.

The ${ }^{13} \mathrm{C}$ NMR DEPT spectrum showed 20 carbons, which were interpreted as four methyls, ten methylenes, three methines and three quaternary carbons. The ${ }^{13} \mathrm{C}$ NMR chemical shifts of the four methyls $\left(\delta_{\mathrm{C}} 33.4,24.3,21.4\right.$ and $15.8)$, two of the methylenes $\left(\delta_{\mathrm{C}} 68.8\right.$ and 57.4), the three methines $\left(\delta_{\mathrm{C}} 57.1,56.5\right.$ and 40.7$)$ and the three quaternary carbons $\left(\delta_{\mathrm{C}} 78.5,39.4\right.$ and 33.5), along with the ${ }^{1} \mathrm{H}$ NMR, ${ }^{1} \mathrm{H}-{ }^{-} \mathrm{H}$ COSY, HSQC and HMBC data (Table 1, Figure 2), were found to be consistent with an 8,15-epoxylabdane structure similar to compound $\mathbf{1}$. The ${ }^{1} \mathrm{H}-{ }^{1} \mathrm{H}$ COSY correlations $(\mathrm{H}-16 / \mathrm{H}-13)$ and the HMBC correlations (H-16/C-12, C-13, C-14) established the structure of 6 as an $8 \alpha, 15$-epoxylabdane in which C-16 bears a hydroxyl group. Complete assignments for the NMR spectra of compound 6 were achieved by ${ }^{1} \mathrm{H}-{ }^{1} \mathrm{H}$ COSY, HSQC and HMBC (Table 1). The structure of compound $\mathbf{6}$ was established as $8 \alpha, 15$-epoxylabdan-16-ol (Figure 1).

The hydrolysis of $\mathbf{2}$ (with a $4 \%$ solution of $\mathrm{KOH} / \mathrm{MeOH}$, at room temperature, $2 \mathrm{~h}$ ) led to the isolation of a product whose NMR spectra and optical rotation data were identical with those of the natural alcohol 6. Colorless crystals of the hydrolysis product (6) were obtained by slow crystallization in $4: 1$ hexane/EtOAc and were found to have a melting point of $119-120{ }^{\circ} \mathrm{C}$. The relative stereochemistry for compound 6 at C-5, C-8, C-9 and C-16 was established by single crystal $\mathrm{X}$-ray diffraction analysis of the hydrolysis product, which was determined to be $8 \alpha, 15$-epoxylabdan16 $\beta$-ol (Figure 4).

Compound 7 was obtained as a colorless oil with an $[\alpha]_{D}^{25}$ value of $+25.2^{\circ}\left(c 0.16, \mathrm{CHCl}_{3}\right)$. The HR-TOF-EIMS presented a molecular ion peak at $\mathrm{m} / \mathrm{z} 294.2561$ (calculated at 294.2559), suggesting a tricyclic structure with a molecular formula of $\mathrm{C}_{19} \mathrm{H}_{34} \mathrm{O}_{2}$. The IR spectrum revealed bands characteristic of a hydroxyl group $\left(3426 \mathrm{~cm}^{-1}\right)$ and an ether $\left(1072 \mathrm{~cm}^{-1}\right)$. 


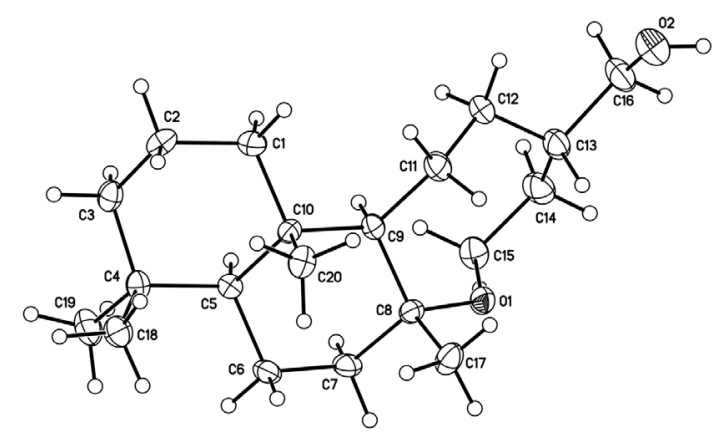

Figure 4. Molecular structure of 6 generated by X-ray diffraction.

The ${ }^{1} \mathrm{H}$ NMR spectrum of $\mathbf{7}$ displayed features similar to those of 6 (Table 2), except that the H-16 signal was absent and the $\mathrm{H}-13$ signal was $2.00 \mathrm{ppm}$ downfield compared to the same signal in compound $\mathbf{6}$. The deshielding of H-13 may be explained by the presence of a geminal hydroxyl group. The concomitant downfield shift of the C-13 signal to $\delta_{\mathrm{C}} 71.53(\Delta \delta \mathrm{ca} .31 \mathrm{ppm})$ is also indicative of an hydroxyl group located at C-13. NOESY correlations (H-9/H-5, Me-18 and H-13/H-9, H-5, Me-18) indicated that $\mathrm{H}-5, \mathrm{H}-9, \mathrm{H}-13$ and Me-18 were on the $\alpha$-face of the molecule; consequently, C-9 and C-13-OH were $\beta$ oriented (Figure 3 ). Additional NOESY correlations (Me-17/Me-19, Me-20) suggested that these methyl groups were also $\beta$ oriented. Thus, the structure of compound 7 was established as $8 \alpha, 15$-epoxy-16-norlabdan-13 $\beta$-ol. Our group has already reported a related $8 \alpha, 15$-epoxy16-norlabdan-13-one from the same plant. ${ }^{6}$

Earlier studies on this plant ${ }^{6}$ were conducted with an extract obtained by Soxleht extraction and doubts remained if the 8,15-epoxy ring was an artifact of the extraction process. However, the same scaffold was isolated from the extract obtained by maceration at room temperature with a different solvent. Therefore, the 8,15-epoxylabdanes can be confirmed as natural products and not artifacts.

A genotoxicity analysis of the induction of micronuclei by compounds $\mathbf{2 , 3}$ and $\mathbf{6}$ is presented in Table 3, which shows the frequency of micronucleated binucleated cells (MNBN, \%), the number of micronuclei per binucleated cell (MN/BN) and the decrease in cell proliferation due to the frequency of binucleated cells (\%). These compounds showed no statistically significant increase in genotoxicity. No mutagenic activity was observed in the Ames test (Table 4) on all the strains tested in the presence or the absence of S9 mix. The cytotoxicities of compounds $\mathbf{2}$, $\mathbf{3}$ and $\mathbf{6}$ were analyzed in V79 cells by the MTT assay. The data in Table 5 shows that cytotoxicity was evident at the lowest concentration tested. From the three compounds, 6 was the most cytotoxic, resulting in less than $50 \%$ survival at an exposure of $25 \mu \mathrm{g}$ per well. At the highest
Table 2. ${ }^{1} \mathrm{H}$ and ${ }^{13} \mathrm{C}$ NMR data and HMBC correlations of compound $7^{\mathrm{a}}$

\begin{tabular}{|c|c|c|c|}
\hline \multirow{2}{*}{ Position } & \multicolumn{3}{|c|}{7} \\
\hline & $\delta{ }^{13} \mathrm{C}$ & $\delta^{\prime} \mathrm{H}(\mathrm{mult}, \mathrm{nH}, J / \mathrm{Hz})$ & HMBC \\
\hline 1 & 40.5 & $\begin{array}{c}0.90(\mathrm{~m}, 1 \mathrm{H}) \\
1.77(\mathrm{dt}, 1 \mathrm{H}, 13.7,3.4)\end{array}$ & $2,3,5,9,10,20$ \\
\hline 2 & 18.7 & $\begin{array}{c}1.42(\mathrm{ddd}, 1 \mathrm{H}, 14.3,7.3 \\
3.6) \\
1.59(\mathrm{~m}, 1 \mathrm{H})\end{array}$ & $1,3,4,10$ \\
\hline 3 & 41.9 & $\begin{array}{c}1.14(\mathrm{~m}, 1 \mathrm{H}) \\
1.31(\mathrm{dt}, 1 \mathrm{H}, 14.4,4.4)\end{array}$ & $1,2,4,5,18,19$ \\
\hline 4 & 33.4 & & \\
\hline 5 & 56.3 & $0.81(\mathrm{~m}, 1 \mathrm{H})$ & $1,7,9,18$ \\
\hline 6 & 20.2 & $\begin{array}{l}1.38(\mathrm{~m}, 1 \mathrm{H}) \\
1.58(\mathrm{~m}, 1 \mathrm{H})\end{array}$ & $4,5,8,10$ \\
\hline 7 & 37.3 & $\begin{array}{l}1.52(\mathrm{~m}, 1 \mathrm{H}) \\
1.58(\mathrm{~m}, 1 \mathrm{H})\end{array}$ & $5,6,8,9,17$ \\
\hline 8 & 78.8 & & \\
\hline 9 & 51.3 & $1.39(\mathrm{~m}, 1 \mathrm{H})$ & $\begin{array}{c}1,8,10,11,12, \\
17,20\end{array}$ \\
\hline 10 & 38.7 & & \\
\hline 11 & 20.4 & $\begin{array}{l}1.27(\mathrm{~m}, 1 \mathrm{H}) \\
1.65(\mathrm{~m}, 1 \mathrm{H})\end{array}$ & $8,9,10,13$ \\
\hline 12 & 36.5 & $\begin{array}{c}1.66(\mathrm{~m}, 1 \mathrm{H}) \\
2.10(\mathrm{ddd}, 1 \mathrm{H}, 13.4,9.4 \\
4.7)\end{array}$ & $9,11,13,14$ \\
\hline 13 & 71.5 & $3.83(\mathrm{td}, 1 \mathrm{H}, 10.2,3.8)$ & $11,12,14,15$ \\
\hline 14 & 39.2 & $1.83(\mathrm{~m}, 2 \mathrm{H})$ & $12,13,15$ \\
\hline 15 & 57.5 & $\begin{array}{c}3.58(\mathrm{dt}, 1 \mathrm{H}, 13.0,4.2) \\
3.72(\mathrm{ddd}, 1 \mathrm{H}, 13.0,10.2 \\
3.2)\end{array}$ & $8,13,14$ \\
\hline 17 & 23.7 & $1.15(\mathrm{~s}, 3 \mathrm{H})$ & $7,8,9$ \\
\hline 18 & 33.5 & $0.86(\mathrm{~s}, 3 \mathrm{H})$ & $3,4,5,19$ \\
\hline 19 & 21.5 & $0.78(\mathrm{~s}, 3 \mathrm{H})$ & $3,4,5,18$ \\
\hline 20 & 15.3 & $0.81(\mathrm{~s}, 3 \mathrm{H})$ & $1,5,9,10$ \\
\hline
\end{tabular}

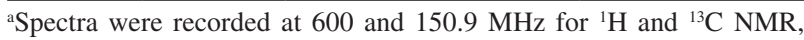
respectively; 2D NMR experiments recorded in accordance; coupling constants are in parenthesis; ${ }^{b}$ overlapped signal.

concentration tested (250 $\mu \mathrm{g}$ per well), cell viability for all compounds was below 9\%, and compound 6 exhibited the highest overall cytotoxicity in V79 cells. According to the micronucleus assay, none of the three compounds are genotoxic in V79 cells at the concentrations tested, indicating that genotoxic activity is apparently not the main reason for their cytotoxicity.

The hexane (1 and 2), dichloromethane and ethyl acetate extracts of $E$. viscosa were tested by the DPPH and ABTS methods to measure their antioxidant capacities; the peroxide values and the total phenolic contents were also determined. The extracts have a very low antioxidant capacity with respect to both DPPH (Figure 5) and ABTS radicals (Figure 6) when compared to a $0.05 \mathrm{mg} \mathrm{mL}^{-1}$ Trolox $^{\circledR}$ solution. The antioxidant capacities of the extracts tested were also expressed in TEAC $\left(\right.$ Trolox $^{\circledR}$ 
Table 3. Effect of compounds $\mathbf{2}, \mathbf{3}$ and $\mathbf{6}$ on the frequency of micronucleated binucleated cells (MNBN, \%) in V79 Chinese hamster cells in the presence (+S9) and absence (-S9) of metabolic activation

\begin{tabular}{|c|c|c|c|c|c|c|}
\hline \multirow{2}{*}{$\begin{array}{l}\text { Test compound / } \\
\left(\mu \mathrm{gL}^{-1}\right)\end{array}$} & \multicolumn{2}{|c|}{$\mathrm{MN} / \mathrm{BN}$} & \multicolumn{2}{|c|}{ MNBN / \% } & \multicolumn{2}{|c|}{$\mathrm{BN} / \%$} \\
\hline & $-\mathrm{S} 9$ & $+\mathrm{S} 9$ & $-\mathrm{S} 9$ & $+\mathrm{S} 9$ & $-\mathrm{S} 9$ & $+\mathrm{S} 9$ \\
\hline \multicolumn{7}{|l|}{2} \\
\hline 0 & $0.003 \pm 0.001$ & $0.002 \pm 0.001$ & $0.300 \pm 0.071$ & $0.167 \pm 0.058$ & $40.950 \pm 14.213$ & $37.400 \pm 2.263$ \\
\hline 10 & $0.005 \pm 0.001$ & $0.000 \pm 0.000$ & $0.450 \pm 0.071$ & $0.000 \pm 0.000$ & $34.600 \pm 1.980$ & $49.950 \pm 5.586$ \\
\hline 25 & $0.004 \pm 0.000$ & $0.003 \pm 0.000$ & $0.400 \pm 0.000$ & $0.003 \pm 0.000$ & $37.700 \pm 2.687$ & $48.950 \pm 15.344$ \\
\hline \multicolumn{7}{|l|}{3} \\
\hline 10 & $0.004 \pm 0.000$ & $0.001 \pm 0.001$ & $0.467 \pm 0.115$ & $0.100 \pm 0.141$ & $39.250 \pm 16.617$ & $35.900 \pm 4.243$ \\
\hline 50 & $0.006 \pm 0.002$ & $0.002 \pm 0.001$ & $0.450 \pm 0.071$ & $0.133 \pm 0.115$ & $45.900 \pm 9.617$ & $40.350 \pm 7.707$ \\
\hline \multicolumn{7}{|l|}{6} \\
\hline 10 & $0.003 \pm 0.001$ & $0.002 \pm 0.002$ & $0.250 \pm 0.071$ & $0.167 \pm 0.153$ & $35.400 \pm 1.414$ & $37.600 \pm 2.546$ \\
\hline 25 & $0.003 \pm 0.000$ & $0.001 \pm 0.001$ & $0.300 \pm 0.000$ & $0.100 \pm 0.100$ & $37.600 \pm 7.495$ & $33.750 \pm 1.626$ \\
\hline \multicolumn{7}{|l|}{ Mytomicin C } \\
\hline $2.5 \mu \mathrm{g} \mathrm{mL}^{-1}$ & $0.154 \pm 0.022$ & - & $10.475 \pm 1.790$ & - & $25.000 \pm 4.243$ & - \\
\hline
\end{tabular}

Cyclophosphamide

$2.0 \mu \mathrm{g} \mathrm{mL}^{-1} \quad-\quad-\quad 0.036 \pm 0.022 \quad-\quad-100 \pm 0.265$

Results are expressed as mean values \pm standard deviations $(\mathrm{SD})(\mathrm{n}=2)$. In each experiment, 1000 binuleated cells were analyzed for the presence of micronuclei. Percentage of binucleated cells (BN) was use as index of cell proliferation. Mytomicin C and cyclophospamide were used as positive controls, dose 0 as negative control. Values are not significant $(p>0.05)$.

Table 4. Mutagenic activity of compounds $\mathbf{2 , 3}$ and $\mathbf{6}$ in the Ames assay in the presence and absence of metabolic activation (S9) (Salmonella typhimurium strains TA 98, 100 and 102)

\begin{tabular}{|c|c|c|c|c|c|c|}
\hline \multirow{2}{*}{$\begin{array}{l}\text { Dose / } \\
\text { ( } \mu \mathrm{g} \text { per plate) }\end{array}$} & \multicolumn{2}{|c|}{ TA $98^{\mathrm{a}}$} & \multicolumn{2}{|c|}{ TA $100^{\mathrm{a}}$} & \multicolumn{2}{|c|}{ TA $102^{\mathrm{a}}$} \\
\hline & $-\mathrm{S} 9$ & $+\mathrm{S} 9$ & $-\mathrm{S} 9$ & +S9 & $-\mathrm{S} 9$ & +S9 \\
\hline \multicolumn{7}{|l|}{2} \\
\hline 0 & $17.5 \pm 3.5$ & $27.5 \pm 9.2$ & $130.5 \pm 29.0$ & $123.5 \pm 20.5$ & $268.0 \pm 56.6$ & $342.0 \pm 31.1$ \\
\hline 5 & $19.05 \pm 2.1$ & $27.0 \pm 8.5$ & $125.0 \pm 15.6$ & $138.5 \pm 0.7$ & $263.5 \pm 122.3$ & $375.0 \pm 15.6$ \\
\hline 25 & $24.0 \pm 2.8$ & $22.0 \pm 2.8$ & $120.0 \pm 22.6$ & $106.5 \pm 26.2$ & $266.0 \pm 73.5$ & $376.0 \pm 36.8$ \\
\hline 50 & $19.0 \pm 4.2$ & $22.5 \pm 3.5$ & $113.0 \pm 4.2$ & $114.0 \pm 25.5$ & $149.0 \pm 103.2$ & $365.0 \pm 7.1$ \\
\hline 250 & $15.0 \pm 4.2$ & $15.5 \pm 0.7$ & $116.0 \pm 7.1$ & $116.0 \pm 28.3$ & $230.5 \pm 118.1$ & $342.0 \pm 14.1$ \\
\hline \multicolumn{7}{|l|}{3} \\
\hline 5 & $10.5 \pm 2.1$ & $23.5 \pm 0.7$ & $128.0 \pm 11.3$ & $98.0 \pm 5.7$ & $254.0 \pm 17.0$ & $273.0 \pm 52.3$ \\
\hline 25 & $16.0 \pm 4.2$ & $22.0 \pm 8.5$ & $126.5 \pm 10.6$ & $120.0 \pm 18.4$ & $304.0 \pm 50.9$ & $401.0 \pm 63.6$ \\
\hline 50 & $16.0 \pm 2.8$ & $23.0 \pm 1.4$ & $121.0 \pm 5.7$ & $123.0 \pm 7.1$ & $262.0 \pm 76.4$ & $348.0 \pm 99.0$ \\
\hline 250 & $11.0 \pm 1.4$ & $20.5 \pm 2.1$ & $88.0 \pm 11.3$ & $111.5 \pm 19.1$ & $212.0 \pm 35.4$ & $297.0 \pm 9.9$ \\
\hline \multicolumn{7}{|l|}{6} \\
\hline 5 & $20.5 \pm 0.7$ & $20.0 \pm 2.8$ & $111.5 \pm 24.7$ & $127.0 \pm 7.1$ & $278.5 \pm 33.2$ & $315.5 \pm 102.5$ \\
\hline 25 & $19.0 \pm 1.4$ & $20.0 \pm 1.4$ & $123.0 \pm 1.4$ & $100.5 \pm 14.8$ & $239.5 \pm 96.9$ & $276.0 \pm 59.4$ \\
\hline 50 & $20.5 \pm 0.7$ & $19.5 \pm 2.1$ & $122.0 \pm 1.4$ & $116.5 \pm 0.7$ & $244.5 \pm 50.2$ & $341.0 \pm 89.1$ \\
\hline 250 & $12.0 \pm 4.2$ & $17.5 \pm 2.1$ & $94.0 \pm 1.4$ & $45.5 \pm 19.1$ & $237.0 \pm 91.9$ & $260.5 \pm 34.6$ \\
\hline \multicolumn{7}{|l|}{ Quercetin } \\
\hline 10 & $284.0 \pm 77.7$ & $1314.5 \pm 102.5$ & & & & \\
\hline \multicolumn{7}{|l|}{ 4-NQO } \\
\hline 10 & & & 1432 & & 2842 & \\
\hline
\end{tabular}

Values are presented as the mean \pm standard error $(\mathrm{n}=2)$. Quercetin and 4-NQO were used as positive controls. Values are not significant $(p>0.05)$. ${ }^{a}$ Number of revertents; 4-NQO: 4-nitroquinoline-1-oxide. 
Table 5. Effect of compounds 2, 3 and $\mathbf{6}$ on cell viability of V79 Chinese hamster cells using the MTT assay

\begin{tabular}{lccc}
\hline $\begin{array}{l}\text { Dose / } \\
(\mu \mathrm{g} \text { per } \text { well })\end{array}$ & $\mathbf{2}$ & $\mathbf{3}$ & $\mathbf{6}$ \\
\cline { 2 - 4 } 25 & $88.6 \pm 21.4$ & $66.5 \pm 26.6$ & $43.0 \pm 12.5$ \\
50 & $48.7 \pm 39.9$ & $37.6 \pm 23.0$ & $35.0 \pm 4.1$ \\
250 & $4.2 \pm 4.6$ & $10.8 \pm 13.0$ & $8.3 \pm 5.9$ \\
\hline
\end{tabular}

aiability is expressed as percentage values relative to control cells. Results are expressed as mean value viability \pm standard deviations $(\mathrm{SD})(\mathrm{n}=3)$. In each independent experiment, four replicate cultures were used.

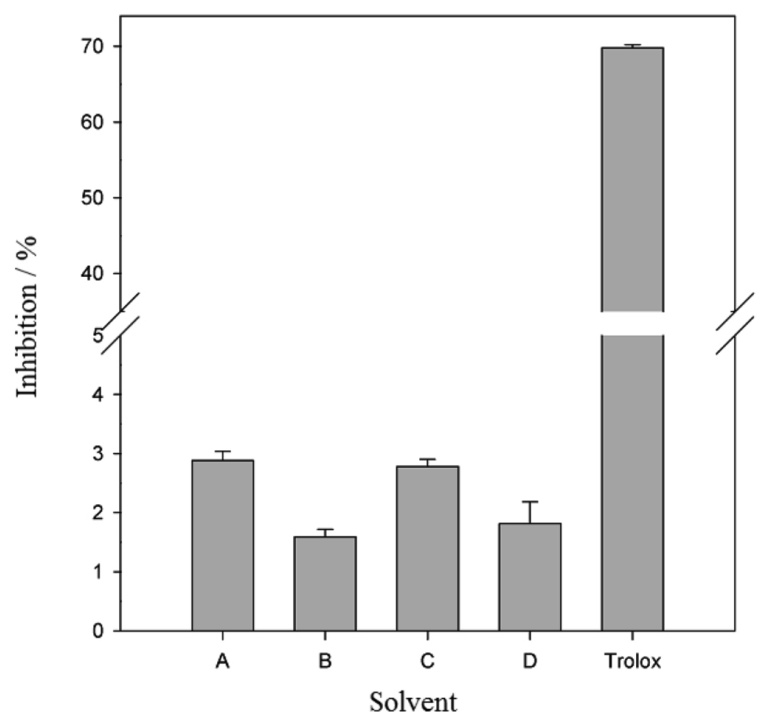

Figure 5. Percentage of inhibition for the DPPH assay $(n=9 \pm$ standard error (SE)) E. viscosa extracts in different solvents. A: dichloromethane; B: hexane 1; C: hexane 2; D: ethyl acetate; Trolox ${ }^{\circledR} 0.05 \mathrm{mg} \mathrm{mL}^{-1}$ as positive control.

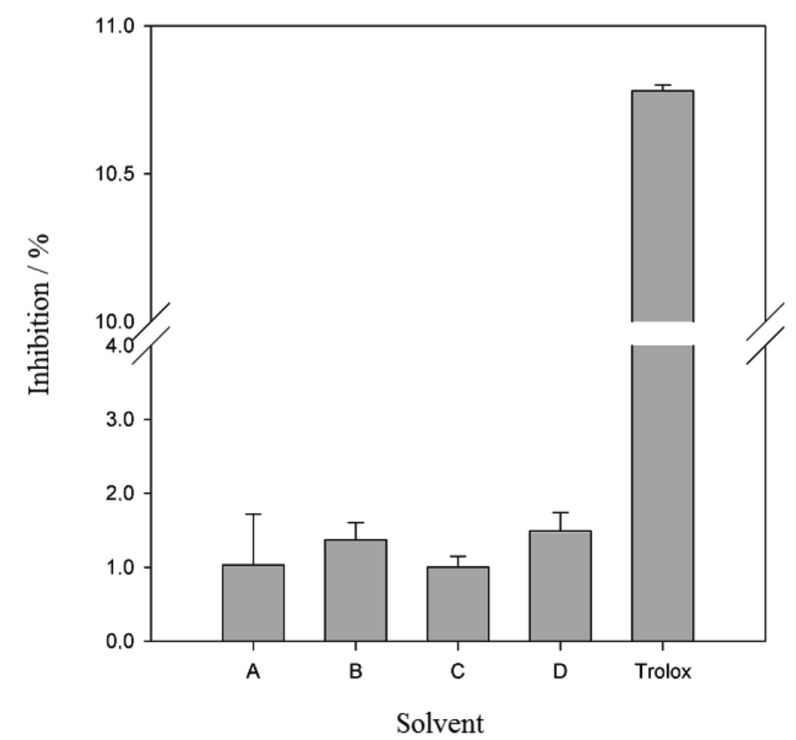

Figure 6. Percentage of inhibition for the ABTS assay $(\mathrm{n}=9 \pm \mathrm{SE})$ by $E$. viscosa extracts in different solvents. A: dichloromethane; B: hexane 1; C: hexane 2; D: ethyl acetate; Trolox ${ }^{\circledR} 0.05 \mathrm{mg} \mathrm{mL}^{-1}$ as positive control. equivalent antioxidant capacity) values (Figure 7), which are defined as the concentration of Trolox ${ }^{\circledR}$ that has the same activity as $1 \mathrm{mmol} \mathrm{L}^{-1}$ of the antioxidant substance investigated. Unfortunately, the TEAC values may not correlate exactly with the antioxidant capacities. There may be a high TEAC value for a compound with a relatively low antioxidant capacity because the products of the reaction of $\mathrm{ABTS}^{++}$with a given compound can also react with $\mathrm{ABTS}^{*+}$, contributing to an increase in the TEAC value. This situation is observed in Figure 7. Thus, it may be concluded that the reaction products are better antioxidants than the initial compounds. ${ }^{18}$ The E. viscosa ethyl acetate extract had the highest phenolic content, $138.66 \pm 0.01$ gallic acid equivalents (GAE), in $\mathrm{mg} \mathrm{g}^{-1}$ of dry extract (Figure 8). Sunflower oil that was submitted to heating after the $8^{\text {th }}$ day resulted in a peroxide value of $105.13 \pm 6.07 \mathrm{meq} \mathrm{O}_{2} \mathrm{~kg}^{-1}$ oil, but in the presence of dichloromethane and ethyl acetate extracts from E. viscosa, this value decreased to $83.70 \pm 0.12$ meq $\mathrm{O}_{2} \mathrm{~kg}^{-1}$ oil and $74.13 \pm 0.09$ meq $\mathrm{O}_{2} \mathrm{~kg}^{-1}$ oil, respectively (Figure 9), showing that these extracts are effective for the protection of sunflower oil from oxidation. Two different populations of E. viscosa were collected, in Serra do Cristo Rei, Huíla, Angola $^{6}$ in July 2001 and the other in the outskirts of Lubango in July of 2003 originating two different hexane extracts, hexane 1 and 2 respectively. Those extracts presented significant differences in the DPPH (Figure 5) ABTS (Figure 6) and total phenolic content assays (Figure 8), although the most significant difference emerges from the TEAC value pointing out to a possible variation in the chemical composition of the phenolic content.

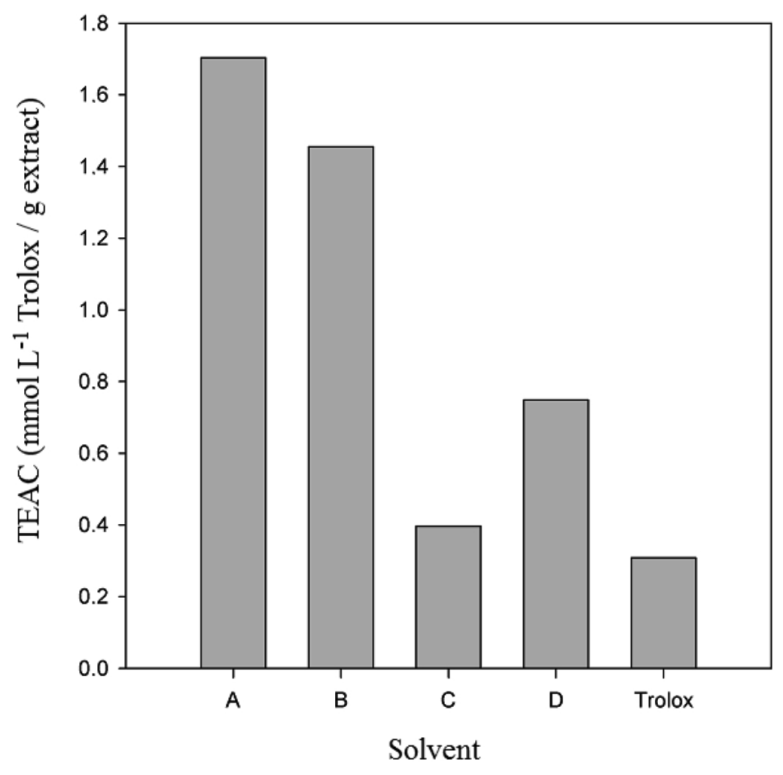

Figure 7. TEAC value for E. viscosa extracts in different solvents. A: dichloromethane; B: hexane 1; C: hexane 2; D: ethyl acetate. 


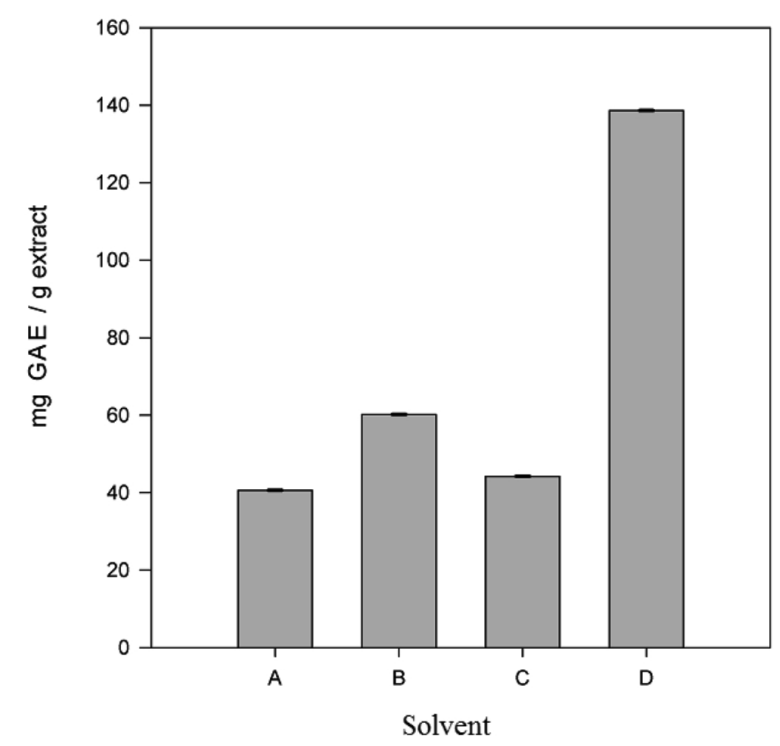

Figure 8. Total phenolic concentration determined by the Folin-Ciocalteau method for E. viscosa extracts in different solvents. A: dichloromethane; B: hexane 1; C: hexane 2; D: ethyl acetate.

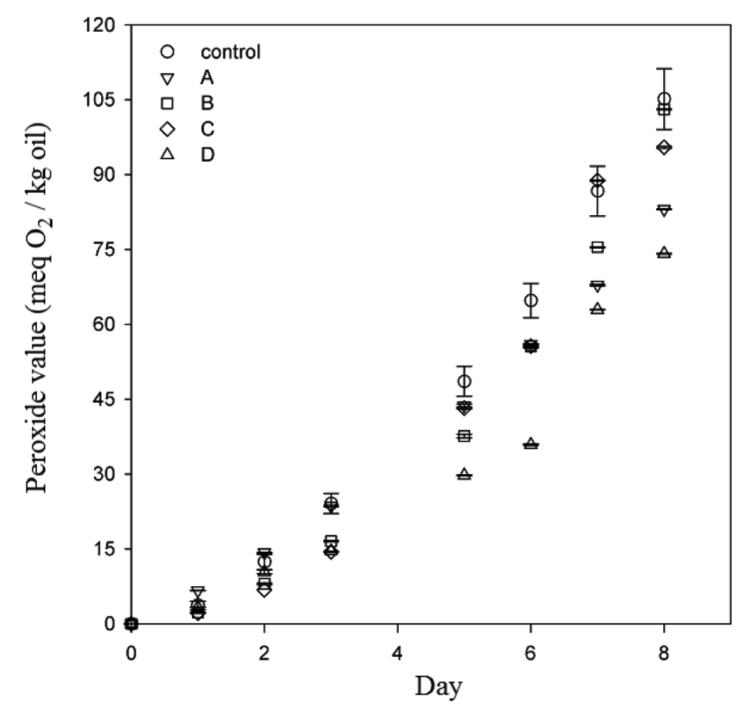

Figure 9. Peroxide value for E. viscosa extracts in different solvents, $(n=3 \pm$ SE). A: dichloromethane; B: hexane 1; C: hexane 2; D: ethyl acetate; control: sunflower oil.

\section{Conclusions}

The present phytochemical investigation of aerial parts of E. viscosa (Retz.) Trin. afforded three new $8 \alpha, 15$-epoxylabdanes $\mathbf{1}, \mathbf{6}$ and $\mathbf{7}$ along with known compounds $8 \alpha, 15$-epoxy-16-norlabdan-

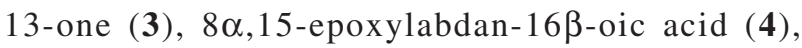
$3 \beta$-(3",4"-dihydroxy)-(E)-cinnamoyloxylup-20(29)-ene (5), 3-(2',3', 4',6'-tetra- $O$-acetyl- $\beta$-D-glucopyranosyloxy)$\beta$-sitosterol (8) and 16-acetoxy-8,15-epoxylabdane (2).

Genotoxicity, mutagenicity and cytotoxicity were tested for compounds $\mathbf{2}, \mathbf{3}$ and $\mathbf{6}$, genotoxic and mutagenic assays were negative but all compounds proved to be cytotoxic and compound $\mathbf{6}$ was shown to be the most cytotoxic of the compounds tested.

Antioxidant capacity of the hexane (1 and 2), dichloromethane and ethyl acetate extracts of E. viscosa were tested but all extracts presented a very low antioxidant capacity. The ethyl acetate extract had the highest phenolic content of all extracts and dichloromethane and ethyl acetate extracts present the best protection to sunflower oil from oxidation.

\section{Supplementary Information}

Crystallographic data (excluding structure factors) for the structure in this work was deposited in the Cambridge Crystallographic Data Centre as supplementary publication number CCDC 860140. 1D and 2D NMR spectra data associated with this article are available free of charge at http://jbcs.sbq.org.br as a PDF file.

\section{Acknowledgements}

This work was partially funded by the projects POCTI/ QUI/39380/2001 and FCOMP-01-0124-FEDER-007430 (under COMPETE with FEDER funding) of the Fundação para a Ciência e Tecnologia (FCT) and the Textile and Paper Materials Center. One of the authors (N'S. N. Sebastião) gratefully acknowledges a GRICES PhD scholarship and INABE (Angola) for financial support.

\section{References}

1. Pant, C. S.; Dhami, K. S.; Asian J. Chem. 2003, 15, 225.

2. Tulloch, A. P.; Phytochemistry 1982, 21, 661.

3. Bultosa, G.; Taylor, J. R. N.; Starch/Stärke 2003, 55, 304.

4. Gargano, A. O.; Aduriz, M. A.; Arelovich, H. M.; Amela, M. I.; Trop. Grasslands 2001, 35, 161.

5. dos Santos, A. F.; Lopes, L. A.; Mata, R. C. S.; de Mendonça, D. I. M. D.; Sant'Ana, A. E. G.; Bioresour. Technol. 2007, 98, 135.

6. Sebastião, N'S. N.; Cordeiro, I. J. S.; dos Santos, A. F.; Gaspar, J. F.; Martins, C.; Rueff, J.; Diakanamwa, C.; Sant'Ana, A. E. G.; de Mendonça, D. I. M. D.; Phytochemistry 2010, 71, 798.

7. Borges, C. M. P.; Diakanawma, C.; de Mendonça D. I. M. D.; J. Braz. Chem. Soc. 2010, 21, 1121.

8. Ahmad, V. U.; Rahman, A.; Handbook of Natural Products Data: Pentacyclic Triterpenoids, vol. 2; Elsevier Science B.V.: Amsterdam, The Netherlands, 1994, p. 1187.

9. Matkowski, A.; Piotrowska, M.; Fitoterapia 2006, 77, 346.

10. Re, R.; Pellegrini, N.; Proteggente, A.; Pannala, A.; Yang, M.; Rice-Evans, C.; Free Radical Biol. Med. 1999, 26, 1231. 
11. Villaño, D.; Fernández-Pachón, M. S.; Moyá, M. L.; Troncoso, A. M.; García-Parrilla, M. C.; Talanta 2007, 71, 230.

12. American Oil Chemists' Society, AOCS Official Method Cd 8-53 In Official Methods and Recommended Practices of the AOCS; Firestone, D., ed; AOCS: Champaign, USA, 2003.

13. Maron, D. M.; Ames, B. N.; Mutat. Res. 1983, 113, 173.

14. van Hummelen, P.; Kirsch-Volders, M.; Mutagenesis 1990, 5 , 203.

15. Caria, H.; Chaveca, T.; Laires, A.; Rueff, J.; Mutat. Res. 1995, 343,85 .
16. Oliveira, N. G.; Castro, M.; Rodrigues, A. S.; Gonçalves, I. C.; Cassapo, R.; Fernandes, A. P.; Chaveca, T.; Toscano-Rico, J. M.; Rueff, J.; Mutagenesis 2001, 16, 369.

17. Ziegler, G.; Spiteller, G.; Flavour Fragance J. 1992, 7, 141.

18. Arts, M. J. T. J; Haenen, G. R. M. M; Voss, H. P.; Bast, A.; Food Chem. Toxicol. 2004, 42, 45.

Submitted: February 3, 2012

Published online: November 1, 2012 